\title{
IGF-1R inhibition induces schedule-dependent sensitization of human melanoma to temozolomide
}

\author{
Roger Ramcharan ${ }^{1}$, Tamara Aleksic ${ }^{1}$, Wilfride Petnga Kamdoum ${ }^{1}$, Shan Gao ${ }^{1}$, \\ Sophia X. Pfister ${ }^{1}$, Jordan Tanner ${ }^{2}$, Esther Bridges ${ }^{1}$, Ruth Asher ${ }^{3}$, Amanda J. Watson ${ }^{4}$, \\ Geoffrey P. Margison ${ }^{4,}{ }^{*}$, Mick Woodcock ${ }^{1}$, Emmanouela Repapi ${ }^{5}$, Ji-Liang Li ${ }^{1}$, \\ Mark R. Middleton ${ }^{6}$, Valentine M. Macaulay ${ }^{1,6}$ \\ ${ }^{1}$ Department of Oncology, Old Road Campus Research Building, Oxford, UK \\ ${ }^{2}$ Biomedical Services, John Radcliffe Hospital, Oxford, UK \\ ${ }^{3}$ Department of Pathology, John Radcliffe Hospital, Oxford, UK \\ ${ }^{4}$ Cancer Research UK Carcinogenesis Group, Paterson Institute for Cancer Research, Manchester, UK \\ ${ }^{5}$ Computational Biology Research Group, Weatherall Institute of Molecular Medicine, Oxford, UK \\ ${ }^{6}$ Oxford Cancer Centre, Churchill Hospital, Oxford, UK \\ *Present address: Centre for Occupational and Environmental Health, University of Manchester, Manchester, UK \\ Correspondence to: \\ Valentine M. Macaulay, e-mail: valentine.macaulay@oncology.ox.ac.uk \\ Keywords: IGF-IR, chemo-sensitization, double strand break, temozolomide, apoptosis \\ Received: August 19, $2015 \quad$ Accepted: October 03, $2015 \quad$ Published: October 15, 2015
}

\section{ABSTRACT}

Prior studies implicate type 1 IGF receptor (IGF-1R) in mediating chemoresistance. Here, we investigated whether IGF-1R influences response to temozolomide (TMZ), which generates DNA adducts that are removed by $0^{6}$-methylguanine-DNA methyltransferase (MGMT), or persist causing replication-associated double-strand breaks (DSBs). Initial assessment in 10 melanoma cell lines revealed that TMZ resistance correlated with MGMT expression $(r=0.79, p=0.009)$, and in MGMTproficient cell lines, with phospho-IGF-1R $(r=0.81, p=0.038)$, suggesting that TMZ resistance associates with IGF-1R activation. Next, effects of IGF-1R inhibitors (IGF-1Ri) AZ3801 and linsitinib (OSI-906) were tested on TMZ-sensitivity, cell cycle progression and DSB induction. IGF-1Ri sensitized BRAF wild-type and mutant melanoma cells to TMZ in vitro, an effect that was independent of MGMT. Cells harboring wild-type p53 were more sensitive to IGF-1Ri, and showed scheduledependent chemo-sensitization that was most effective when IGF-1Ri followed TMZ. This sequence sensitized to clinically-achievable TMZ concentrations and enhanced TMZ-induced apoptosis. Simultaneous or prior IGF-1Ri caused less effective chemosensitization, associated with increased $\mathrm{G} 1$ population and reduced accumulation of TMZ-induced DSBs. Clinically relevant sequential (TMZ ã IGF-1Ri) treatment was tested in mice bearing A375M (V600E BRAF, wild-type p53) melanoma xenografts, achieving peak plasma/tumor IGF-1Ri levels comparable to clinical Cmax, and inducing extensive intratumoral apoptosis. TMZ or IGF-1Ri caused minor inhibition of tumor growth (gradient reduction $13 \%$, $25 \%$ respectively), while combination treatment caused supra-additive growth delay $(72 \%)$ that was significantly different from control $(p<0.01)$, TMZ $(p<0.01)$ and IGF-1Ri $(p<0.05)$ groups. These data highlight the importance of scheduling when combining IGF-1Ri and other targeted agents with drugs that induce replication-associated DNA damage. 


\section{INTRODUCTION}

Metastatic melanoma is highly chemo-resistant: dacarbazine or temozolomide (TMZ) induce responses in $<20 \%$ of patients, with very limited survival benefit $[1,2]$. Approximately $40-50 \%$ of melanomas harbour activating mutations in the RAS-RAF axis, commonly V600E BRAF [3]. The outlook has improved significantly following development of novel forms of immunotherapy and mutant BRAF inhibitors, although responses to the latter are often brief, with early emergence of resistance $[4,5]$.

Type 1 insulin-like growth factor receptor (IGF-1R) is frequently up-regulated in cancers including melanoma, and promotes proliferation and cell survival $[6,7]$. IGF$1 \mathrm{R}$ expression has been associated with an aggressive clinical course and resistance to chemotherapy and targeted agents [8-10]. We previously showed that IGF$1 \mathrm{R}$ depletion blocks survival of BRAF mutant and wildtype (WT) melanoma cells, and enhances chemosensitivity [11]. Recently, we reported that IGF-1R depletion or inhibition delay repair of radiation-induced DNA doublestrand breaks (DSBs), with evidence of impaired repair by both non-homologous end-joining and homologous recombination (HR) $[12,13]$. Many cytotoxic drugs cause DNA damage that is induced during DNA replication, requiring HR for repair [14]. Initiation of HR is very tightly coupled to cell cycle regulation, itself known to be influenced by IGFs [7, 15]. Therefore, as a tool to probe the relationship between IGF-1R and induction of replication-associated DNA damage, we examined responses to $\mathrm{TMZ}$, a methylating agent used to treat glioblastoma multiforme and melanoma [16].

We tested two ATP-competitive IGF-1R tyrosine kinase inhibitors (IGF-1Ri): preclinical compound AZ12253801 (AZ3801), used in our study of effects of IGF-1Ri on the DNA damage response [13], and OSI-906 (linsitinib), developed for clinical evaluation [17-19]. AZ3801 has $\sim 10$ fold selectivity over the insulin receptor (INSR), with $\mathrm{IC}_{50}$ values for inhibition of IGF-1R of $2.1 \mathrm{nM}$ and INSR $19 \mathrm{nM}$ [13]. OSI-906 is $\sim 2$-fold more potent against IGF-1R than INSR $\left(\mathrm{IC}_{50}\right.$ values $35 \mathrm{nM}$ and $75 \mathrm{nM}$ respectively), and recently completed Phase I trials using intermittent or continuous schedules [17-19]. Our data show an association between WT p53 status and sensitivity to IGF-1Ri, reveal that IGF-1R activation correlates with resistance to TMZ, and show that significant enhancement of chemo-sensitivity is induced by a sequential (TMZ $\rightarrow$ IGF-1Ri) schedule. In contrast, IGF-1Ri pre-treatment causes less effective chemo-sensitization, and we show for the first time that pre-inhibiting IGF-1R induces cell cycle delay associated with reduced yield of toxic chemotherapy-induced DNA damage. These findings have clear relevance to the design of future trials of IGF axis inhibitors with chemotherapy.

\section{RESULTS}

\section{IGF-1R phosphorylation associates with resistance of melanoma cell lines to TMZ}

In a human melanoma cell line panel we assessed levels and activation of IGF-1R and its effectors AKT and ERKs, and expression of $O^{6}$-methylguanine-DNA methyltransferase (MGMT) that removes the most toxic TMZ-induced DNA adduct, $O^{6}$-methyguanine $\left(O^{6}\right.$-meG; [16]; Figure 1A). All cell lines expressed IGF$1 \mathrm{R}$, with variable receptor phosphorylation. Reflecting the frequency of RAS-RAF activation [3], phospho-ERK was detectable in all cell lines except CHL1 that harbors WT BRAF/NRAS (Table 1). In a first approach to test the relationship between IGF-1R and chemo-resistance, we evaluated TMZ in viability assays (Figure 1B, Table 1). All cell lines were relatively TMZ-resistant, with $\mathrm{GI}_{50}$ values 155-950 $\mu \mathrm{M}$, above $60 \mu \mathrm{M}$, the clinicallyachievable Cmax [1]. MGMT-deficient SKmel23, A2058 and HMCB were relatively sensitive (TMZ GI $155-215 \mu \mathrm{M})$, and MGMT-positive cell lines more resistant $\left(\mathrm{TMZ} \mathrm{GI}_{50} \geq 250 \mu \mathrm{M}\right.$; Table 1). TMZ GI ${ }_{50}$ values significantly correlated with MGMT expression $(r=0.79$, $p=0.009$; Figure $1 \mathrm{C}$, upper panel), and showed borderline correlation with IGF-1R protein levels $(r=0.64, p=0.052$, Supplementary Figure S1A). In 7 MGMT proficient cell lines, there was significant correlation between $\mathrm{TMZ} \mathrm{GI}_{50}$ and phospho-IGF-1R $(r=0.81, p=0.038$; Figure 1C lower), suggesting association between activated IGF-1R and intrinsic TMZ resistance. These results prompted us to test effects of IGF-1Ri on growth and chemo-resistance.

\section{Cells that harbor WT p53 are more sensitive to IGF-1R inhibition}

Initial experiments tested sensitivity to IGF-1R inhibitor OSI-906, which was shown to be capable of blocking IGF-1R activation for $\geq 72 \mathrm{hr}$ in A375M cells (Figure 1D). In the cell line panel, OSI-906 caused variable concentration-dependent inhibition of melanoma cell viability (Figure 1E), with $\mathrm{GI}_{50}$ values from the nanomolar to low micromolar range (Table 1). These are clinically achievable concentrations: continuous OSI-906 dosing at $150 \mathrm{mg}$ BID achieves plasma levels of $\sim 1000-2000 \mathrm{ng} /$ $\mathrm{ml}(2.4-4.8 \mu \mathrm{M})$, while $600 \mathrm{mg}$ OSI-906 intermittently achieves Cmax of $\sim 8000 \mathrm{ng} / \mathrm{ml}(\sim 20 \mu \mathrm{M})$, remaining at $24 \mathrm{hr}$ above $1 \mu \mathrm{M}$, predicted to be required for efficacy $[18,19]$. Here, there was no correlation between OSI-906 sensitivity and total/activated IGF-1R in the melanoma cell lines, and no evidence that downstream pathway activation due to PTEN loss, BRAF or NRAS mutation was associated with IGF-1Ri resistance, consistent with our previous data using IGFIR gene silencing [11]. We noted that the three most IGF-1Ri-resistant cell lines 

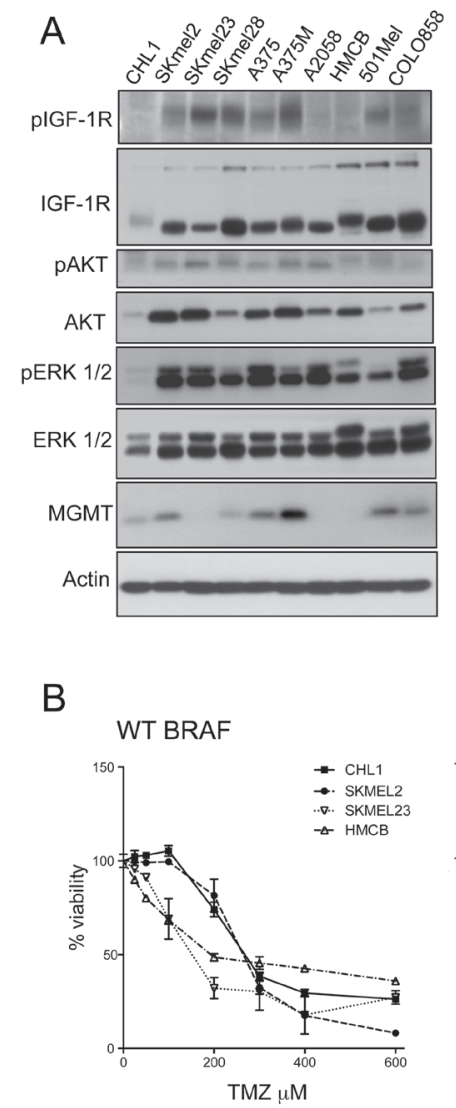

C
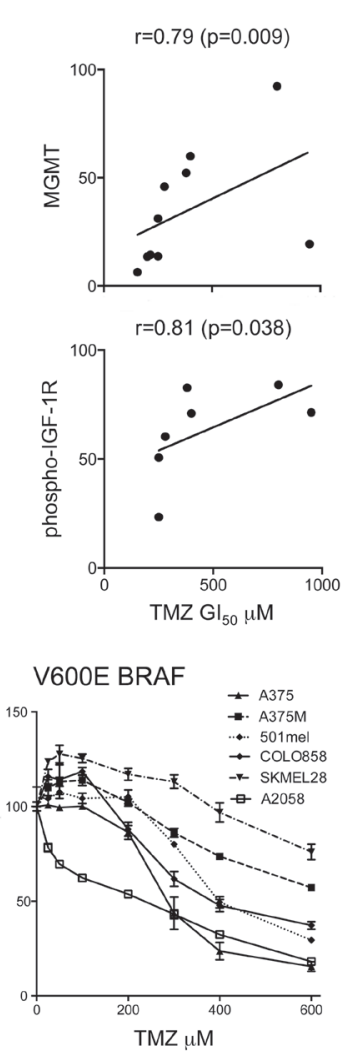
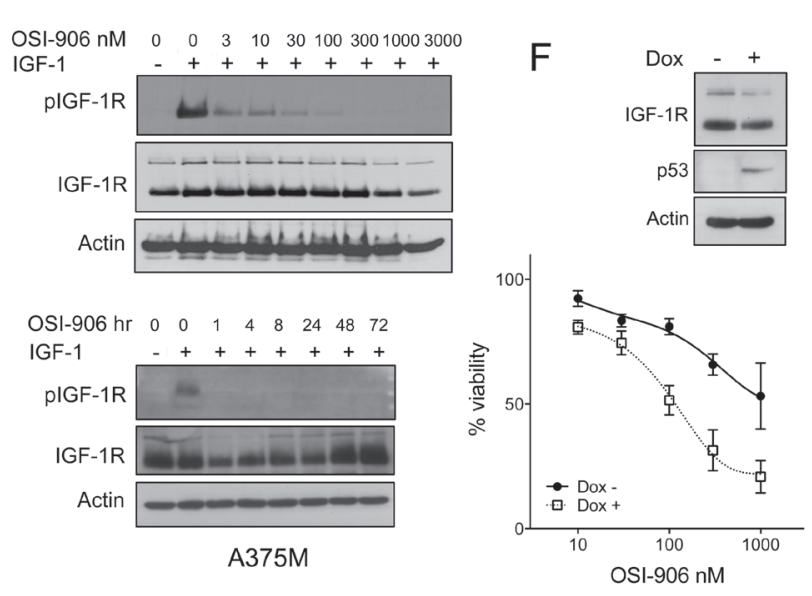

E

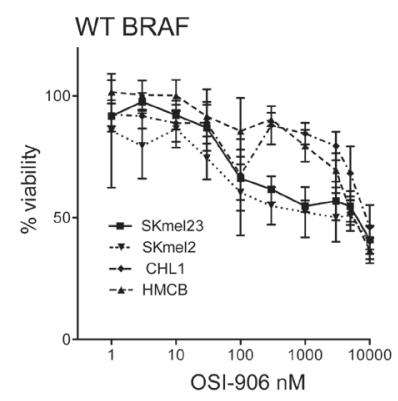

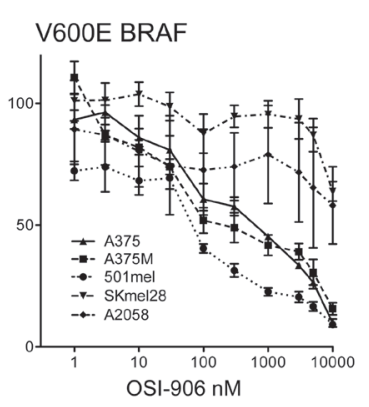

Figure 1: IGF axis association with TMZ resistance and p53 status. A. Whole cell extracts analyzed by western blotting. Similar results were obtained in a second set of independent lysates. B. Cells were treated with TMZ or vehicle, after 5 days CellTiter Glo viability assays were performed and data were expressed as \% viability in TMZ-untreated cultures. Graphs: pooled results from 2 independent assays (6 data points) expressed as mean \pm SEM \% viability. C. Correlation between TMZ $\mathrm{GI}_{50}$ and upper: MGMT; lower: phospho-IGF1R, quantified from western blots in A, corrected for actin loading. D. Serum-starved A375M cells treated with: upper, OSI-906 for 1 hr; lower: $1 \mu \mathrm{M}$ OSI-906 for 1-72 hr, and in the final $15 \mathrm{~min}$ with $50 \mathrm{nM}$ IGF-1. E. Cells were treated with OSI-906 or vehicle, and after 5 days viability assayed as B). F. B231 cells treated with solvent or $2 \mu \mathrm{g} / \mathrm{ml}$ doxycycline for $24 \mathrm{hr}$, and lysed for western blot (inset) or treated with solvent or OSI-906 as E) and viability assayed after 5 days. Graph: data from $n=3$ assays; bars, SEM. GI ${ }_{50}$ values were $>1 \mu \mathrm{M}$ in p53 null cells, $116 \mathrm{nM}$ in p53-positive cells.

$\left(\mathrm{GI}_{50} \sim 10 \mu \mathrm{M}\right.$ or greater) harbored mutant p53 (Table 1). Given that these cell lines are genetically heterogeneous, we tested the relationship between $\mathrm{p} 53$ and response to IGF-1Ri in p53-null B231 cells, in which expression of WT p53 was induced by doxycycline (Figure 1F; [20]. WT p53 is reported to suppress IGF-1R expression [21], but did not influence IGF-1R levels here. The p53 null cells were relatively resistant to OSI-906 $\left(\mathrm{GI}_{50}>1 \mu \mathrm{M}\right)$, and doxycycline-treated cells more sensitive $\left(\mathrm{GI}_{50} 116 \mathrm{nM}\right)$, indicating $\geq 8$-fold sensitization to OSI-906. Thus in both this isogenic model and the melanoma cell lines, lack of WT p53 correlated with relative resistance to IGF-1Ri.

\section{IGF-1R inhibition induces MGMT-independent sensitization of BRAF WT and mutant melanoma cells to TMZ}

We next assessed whether IGF-1Ri modifies response to TMZ in vitro, testing OSI-906 and AZ3801 in BRAF mutant A375M and BRAF WT CHL1, relatively TMZ-resistant (TMZ GI $\left.{ }_{50} 800 \mu \mathrm{M}\right)$ and sensitive $(250 \mu \mathrm{M})$, respectively (Table 1$)$. Like OSI906, AZ3801 caused dose-dependent IGF-1R inhibition for up to $72 \mathrm{hr}$ (Figure 2A). On testing responses to TMZ alone or with IGF-1Ri in survival assays, both OSI-906 and AZ3801 induced dose-dependent TMZ sensitization in each cell line (Figure 2B, 2C, Supplementary Figure 1B-1C). The effect size was similar with both inhibitors, and comparable to TMZsensitization we previously reported in IGF-1R-depleted melanoma cells [11], supporting the contention that sensitization was related to IGF-1R inhibition. To explore the molecular basis for chemosensitization, we performed caspase 3/7 activity assays (Figure 2D) and western blotting for PARP cleavage (Supplementary Figure S2A), detecting increased TMZ-induced apoptosis in IGF-1R inhibited cells after $24-48 \mathrm{hr}$. However, the effect of AZ3801 on apoptosis did 
Table 1: Characteristics of melanoma cell line panel

\begin{tabular}{|c|c|c|c|c|c|c|c|}
\hline \multirow{2}{*}{ Cell line } & \multirow{2}{*}{ BRAF } & \multirow{2}{*}{ NRAS } & \multirow{2}{*}{ PTEN } & \multirow{2}{*}{ p53 } & \multirow{2}{*}{ Other } & \multicolumn{2}{|r|}{$\mathbf{G I}_{50}$} \\
\hline & & & & & & TMZ $\mu \mathrm{M}$ & OSI-906 nM \\
\hline CHL1 & WT & WT & WT & Mut & CDKN2A & 250 & 9200 \\
\hline SKmel2 & WT & Mut & WT & Mut & - & 250 & 3420 \\
\hline SKmel23 & WT & WT & Del & WT & - & 155 & 5960 \\
\hline SKmel28 & Mut & WT & Mut & Mut & EGFR & 950 & $>10000$ \\
\hline A375 & Mut & WT & WT & WT & CDKN2A & 280 & 800 \\
\hline A375M & Mut & WT & WT & WT & CDKN2A & 800 & 150 \\
\hline A2058 & Mut & WT & Mut & Mut & CDKN2A & 200 & $>10000$ \\
\hline HMCB & WT & Mut & WT & Mut & - & 215 & 5880 \\
\hline $501 \mathrm{mel}$ & Mut & WT & WT & Mut & CTNNB1 & 400 & 60 \\
\hline COLO858 & Mut & WT & WT & WT & - & 380 & ND \\
\hline
\end{tabular}

Genotypes from http://www.sanger.ac.uk/genetics/CGP/CellLines/, www-p53.iarc.fr/CellLineCriteria.asp and references

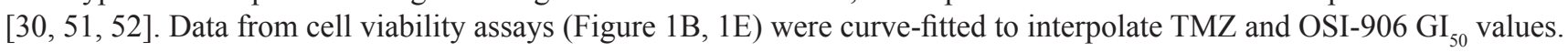

not increase with TMZ concentration, unlike the pattern of chemo-sensitization (Figure 2B-2C), suggesting that chemo-sensitization was unlikely to be wholly attributable to apoptosis induction at these early time-points. Therefore, we next investigated whether IGF-1R influences repair of TMZ-induced DNA damage.

The most toxic alkylated base lesion produced by TMZ is $O^{6}-\mathrm{meG}$, which can be directly repaired by methyl group transfer to a cysteine residue in the MGMT active site pocket [16]. MGMT downregulation is associated, as here (Figure 1C upper), with melanoma sensitivity to TMZ in vitro, although not clinically [22]. Other base lesions include N7-meG, the commonest TMZ-induced lesion, which undergoes spontaneous depurination to generate toxic apurinic (AP) sites, and N3meA, which is intrinsically cytotoxic. Both lesions can be excised by 3-alkyladeinine DNA glycosylase (AAG) [23]. To test whether IGF-1Ri influences MGMT and AAG, we first performed chemo-sensitivity assays in MGMTnull SKmel23 cells, which are highly TMZ sensitive, but even so IGF-1R induced further sensitization (Figure 2E). Secondly, in MGMT-proficient CHL1 and A375M, MGMT activity/expression was unaffected by IGF-1Ri (Supplementary Figure 2B left panel, 2C). MGMT assay specificity was supported by abolition of MGMT activity in CHL1 and A375M by MGMT substrate analogue $O^{6}$-Benzylguanine (O6BG), and by undetectable MGMT activity in SKmel23 (Supplementary Figure 2B left panel). Similarly, IGF-1Ri did not influence AAG activity or TMZ-induced $O^{6}-\mathrm{meG}$ or N7-meG adducts (Supplementary Figure 2B right panel, 2D-2E).
Furthermore, AZ3801 was capable of sensitizing to TMZ in CHL1 cells in which MGMT was inhibited by O6BG (Figure 2F). These results suggest that with respect to TMZ-sensitization, IGF-1R does not function in the same pathway as MGMT.

\section{IGF-1R inhibition induces schedule-dependent chemo-sensitization of melanoma cells}

If MGMT levels are inadequate, $O^{6}-\mathrm{meG}$ persists and undergoes post-replicative mispairing to form G:T pairs that are substrates for mismatch repair. Repeated 'futile cycles' of exonuclease activity and mispairing lead to extension of single-stranded gaps, resulting after $\geq 2$ rounds of replication in replication fork collapse and formation of DSBs [16]. Given that IGFs are well-known to promote cell cycle progression [7], it is plausible that inhibiting this function could influence accumulation of replication-associated DSBs. As an initial step to investigate interactions between the IGF axis and TMZ-response, we tested whether chemo-sensitization is influenced by sequencing IGF-1Ri with respect to TMZ. Based on initial chemo-sensitivity data (Figure 2B-2C), we first tested each drug separately to choose concentrations for combination experiments, using TMZ at $100-250 \mu \mathrm{M}$, and OSI-906 at $300-1000 \mathrm{nM}$ in CHL1 and $30-300 \mathrm{nM}$ in $\mathrm{A} 375 \mathrm{M} ; 1000 \mathrm{nM}$ was too toxic in these cells for combination testing (Figure 3A-3B). We next tested whether chemo-sensitization is influenced by sequencing of IGF-1Ri, using schedules illustrated in Figure 3C. There was no evidence of antagonism (ie no 


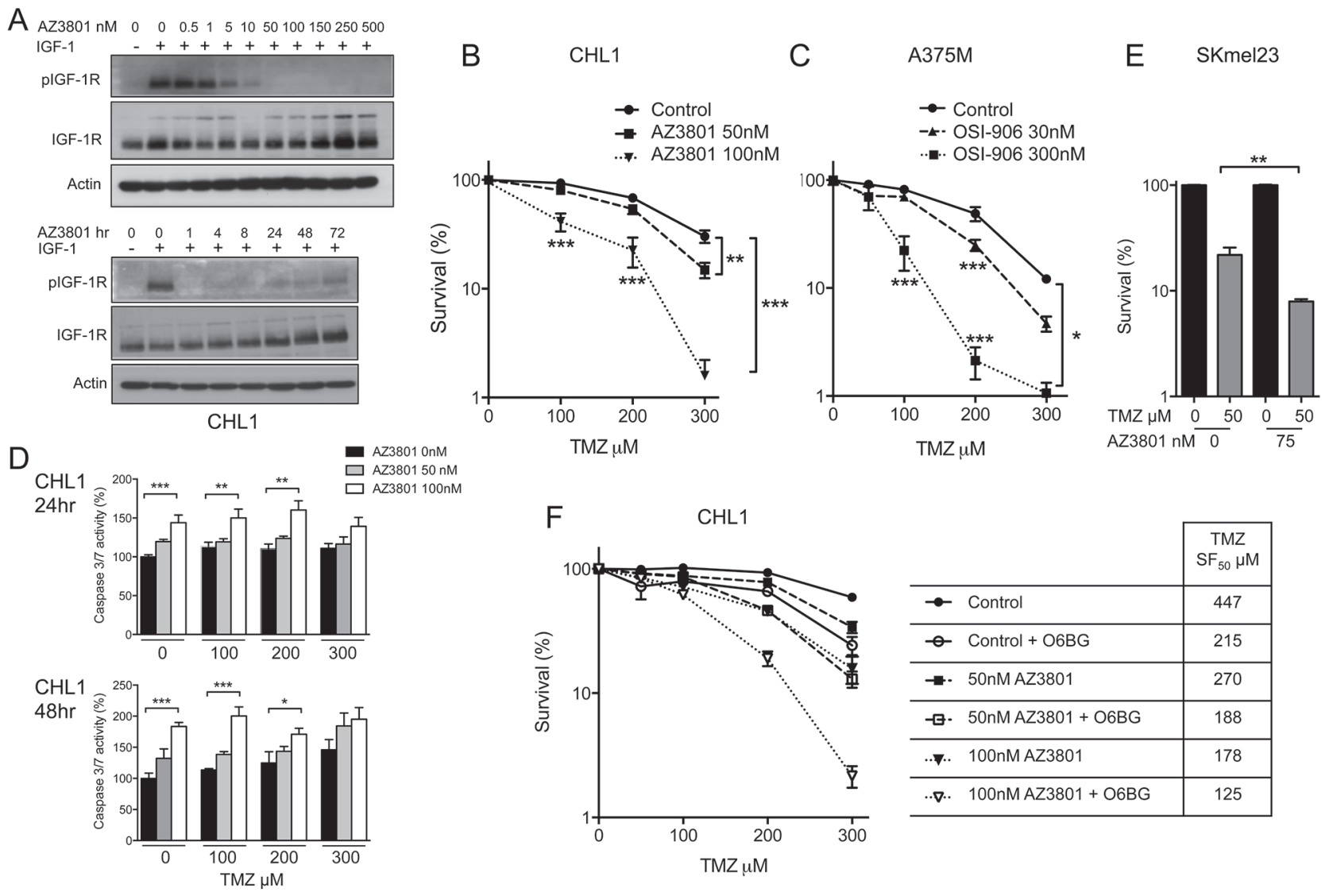

Figure 2: IGF-1R inhibition induces MGMT-independent sensitization of BRAF WT and mutant melanoma cells to

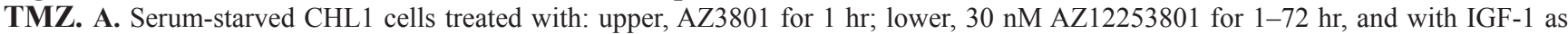
Figure 1D. B. CHL1 and C. A375M cells treated with TMZ alone or with AZ3801 or OSI-906. Graphs: mean \pm SEM \% cell survival from $n=3$ independent assays in each cell line. IGF-1Ri-treated cells were sensitized to TMZ $\left(* p<0.05,{ }^{* *} p<0.01, * * * p<0.001\right)$. D. Graphs: mean \pm SEM caspase activity (\% signal in solvent-treated controls) from $n=2$ independent assays in CHL1 cells, each with triplicate samples. AZ3801 enhanced apoptosis after $24 \mathrm{hr}$ (upper) and $48 \mathrm{hr}$ (lower; ${ }^{*} p<0.05,{ }^{* *} p<0.01$, ${ }^{* * *} p<0.001$ ). E. SKmel23 cells treated

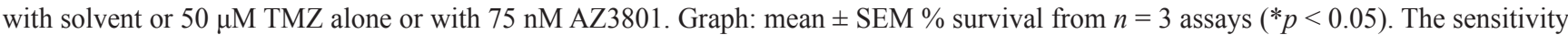
of SKmel23 to IGF-1Ri precluded testing of AZ3801 > $75 \mathrm{nM}$. F. CHL1 cells pre-treated for $2 \mathrm{hr}$ with $10 \mu \mathrm{M}$ O6BG prior to TMZ alone or with AZ3801. Graph: pooled data from $n=2$ survival assays from which were derived TMZ SF ${ }_{50}$ values, shown in legend. In cultures treated with $300 \mu \mathrm{M}$ TMZ, O6BG suppressed survival of AZ3801-untreated controls from $59 \pm 3 \%$ to $24 \pm 4 \%(p<0.001)$, with $50 \mathrm{nM}$

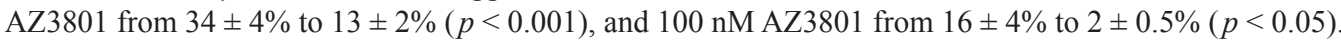

increase in TMZ SF $_{50}$ in OSI-906-treated cells), although cells pre-treated with $30 \mathrm{nM}$ OSI-906 were no more TMZ-sensitive than controls. With this exception, IGF1R-inhibited cells showed dose-dependent sensitization to TMZ (Figure 3D), most effectively when OSI-906 was applied $24 \mathrm{hr}$ after TMZ, compared with cells that were pre-treated or simultaneously-treated. Notably, posttreatment with $300 \mathrm{nM}$ OSI-906 achieved TMZ $\mathrm{SF}_{50}$ of $45 \mu \mathrm{M}$ (Figure 3D, right panel), representing $>5.5$ fold sensitization compared with control (OSI-906-untreated) cells. This $\mathrm{SF}_{50}$ value is below the Cmax of TMZ $(\sim 11 \mu \mathrm{g} /$ $\mathrm{ml}, \sim 60 \mu \mathrm{M})$ administered clinically as a single agent [1]. Equivalent experiments in CHL1 cells confirmed TMZsensitization, but there was no difference in efficacy when IGF-1Ri was added before, concurrently or after TMZ (Supplementary Figure 3A-3B).

\section{IGF-1R inhibition influences cell cycle distribution and DNA damage induction post-TMZ}

Aiming to understand the basis for scheduledependent chemo-sensitization of A375M cells and the lack of sequence variation in CHL1, we investigated changes in cell cycle distribution. After $24 \mathrm{hr}$ exposure to OSI-906 or AZ3801, there was increase in G1 and reduction in S phase fraction (Supplementary Figure S4AS4B), consistent with the ability of IGFs to promote G1 to $\mathrm{S}$ transition [7]. TMZ-treated cells showed an increased G2 population and progressive reduction in S-phase, also evident upon combination treatment and most pronounced at $72 \mathrm{hr}$ (Supplementary Figure S4A-S4B). Fixing on this $72 \mathrm{hr}$ post-TMZ time-point, we tested effects of 

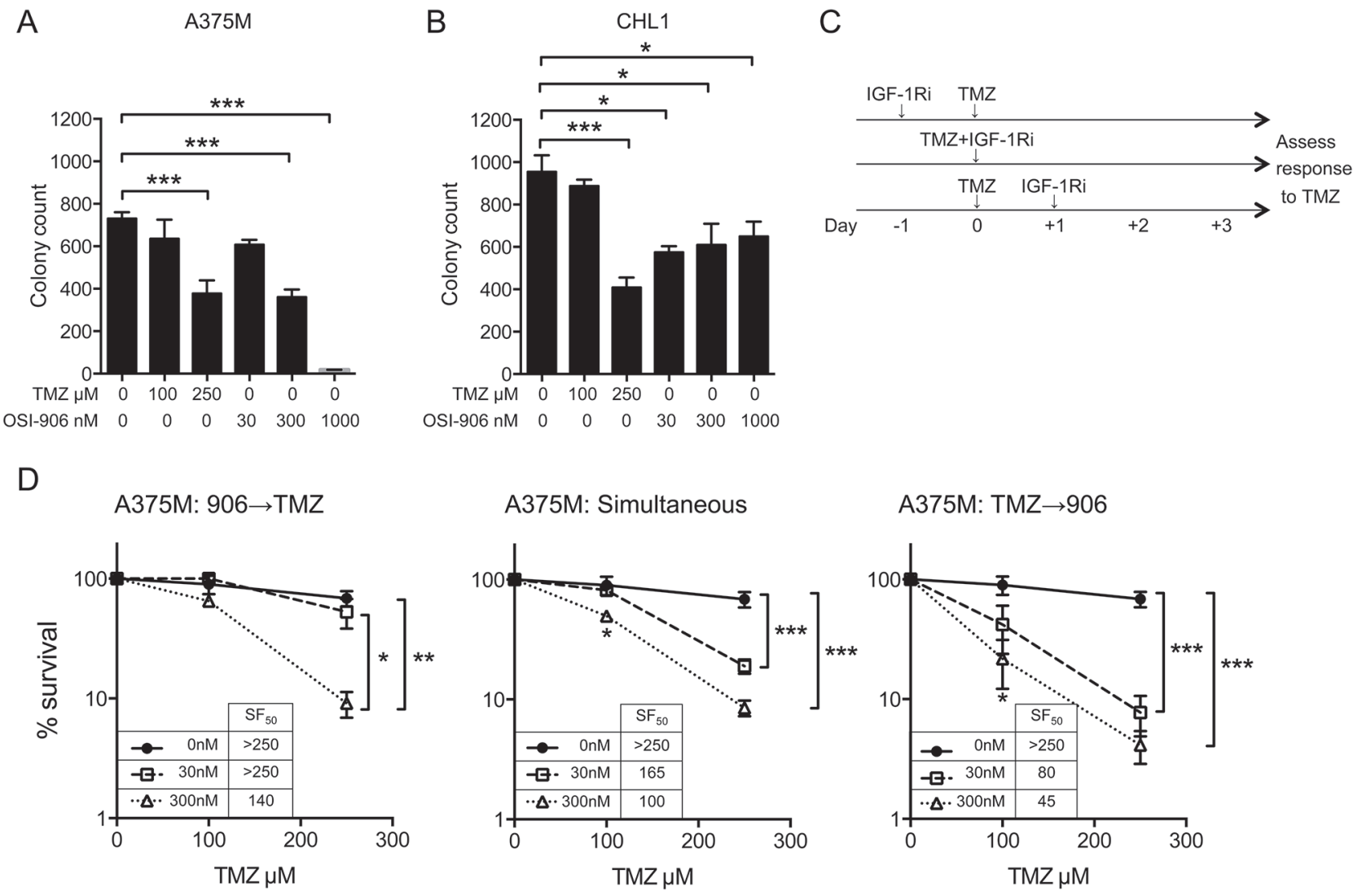

Figure 3: IGF-1R inhibition induces schedule-dependent sensitization to TMZ. A. A375M, B. CHL1 cells were treated with solvent, OSI-906 or TMZ. Graphs: mean \pm SEM $\%$ survival from $n=2$ assays, each with triplicate dishes (6 data points). Cell survival was inhibited in both cell lines by $250 \mu \mathrm{M} \mathrm{TMZ}$ and by OSI-906 at $300-1000 \mathrm{nM}$ in A375M, and 30-1000 $\mathrm{nM}$ in CHL1 (*p $<0.05$, *** $p<$ 0.001). C. Treatment schedules for chemo-sensitivity testing. D. A375M cells treated simultaneously or sequentially with solvent, 30-300 nM OSI-906 and/or TMZ. Graphs: mean \pm SEM \% survival from $n=3$ assays, showing significance of differences from control (OSI-906untreated) cultures $\left(* p<0.05,{ }^{*} p<0.01,{ }^{* *} p<0.001\right)$. Legends: $\mathrm{TMZ} \mathrm{SF}_{50}(\mu \mathrm{M})$ at each OSI-906 concentration.

altering the sequence of IGF-1Ri with respect to TMZ, using the same schedule (Figure 3C) as for chemosensitivity testing. These experiments used $300 \mathrm{nM}$ OSI-906, confirmed to inhibit IGF signaling in both cell lines (Figure 4A). In A375M, TMZ-induced reduction in S-phase and increase in G2 was unaffected by IGF-1R pre-, co- or post- inhibition (Figure 4B-4C). However, the G1 population was significantly increased when IGF-1R was pre- or co- inhibited, compared with TMZ alone and with IGF-1R post-inhibition (Figure 4C). TMZ induced appearance of non-cycling S-phase cells with DNA content between $2 \mathrm{~N}$ and $4 \mathrm{~N}$ but without BrdU incorporation (Figure 4C), suggesting intra-S checkpoint activation [24]. This population was reduced by IGF-1Ri; further work is required to test whether this represents loss of checkpoint integrity. We noted appearance of pre-G1 (likely apoptotic) DNA content, significantly greater in IGF-1R post-inhibited cells, correlating with the pattern of chemo-sensitization (Figure 3D). In contrast, IGF1Ri-treated CHL1 cells showed no change in cell cycle distribution of viable cells, although there was an increase in the pre-G1 population in IGF-1R post-inhibited cells compared with TMZ alone (Figure 4D). To check whether this represented increased apoptosis, we assessed caspase activation by western blot (Figure 4E). TMZ alone generated little positive signal in either cell line, with an increase on addition of OSI-906, particularly upon posttreatment in $\mathrm{A} 375 \mathrm{M}$. We also probed for DNA damage marker $\gamma \mathrm{H} 2 \mathrm{AX}$, noting that relative $\gamma \mathrm{H} 2 \mathrm{AX}$ signals in OSI-906 pre, co- and post- treated A375M cells (Figure 4E left) paralleled the pattern of relative chemo-sensitization (Figure 3D), with more intense signal upon IGF-1R postinhibition. In CHL1, where sequencing did not influence chemo-sensitivity, IGF-1Ri did not influence TMZinduced $\gamma \mathrm{H} 2 \mathrm{AX}$ (Figure 4E right).

The $\gamma \mathrm{H} 2 \mathrm{AX}$ western blot suggested possible excess DNA damage in A375M cells treated with OSI906 after TMZ. Although principally induced by DSBs, non-focal $\gamma \mathrm{H} 2 \mathrm{AX}$ can be induced by other processes including apoptosis $[25,26]$. Therefore, we assessed immunofluorescent $\gamma \mathrm{H} 2 \mathrm{AX}$ foci formed at sites of DSBs. Testing $72 \mathrm{hr}$ post-TMZ to parallel cell cycle and western 

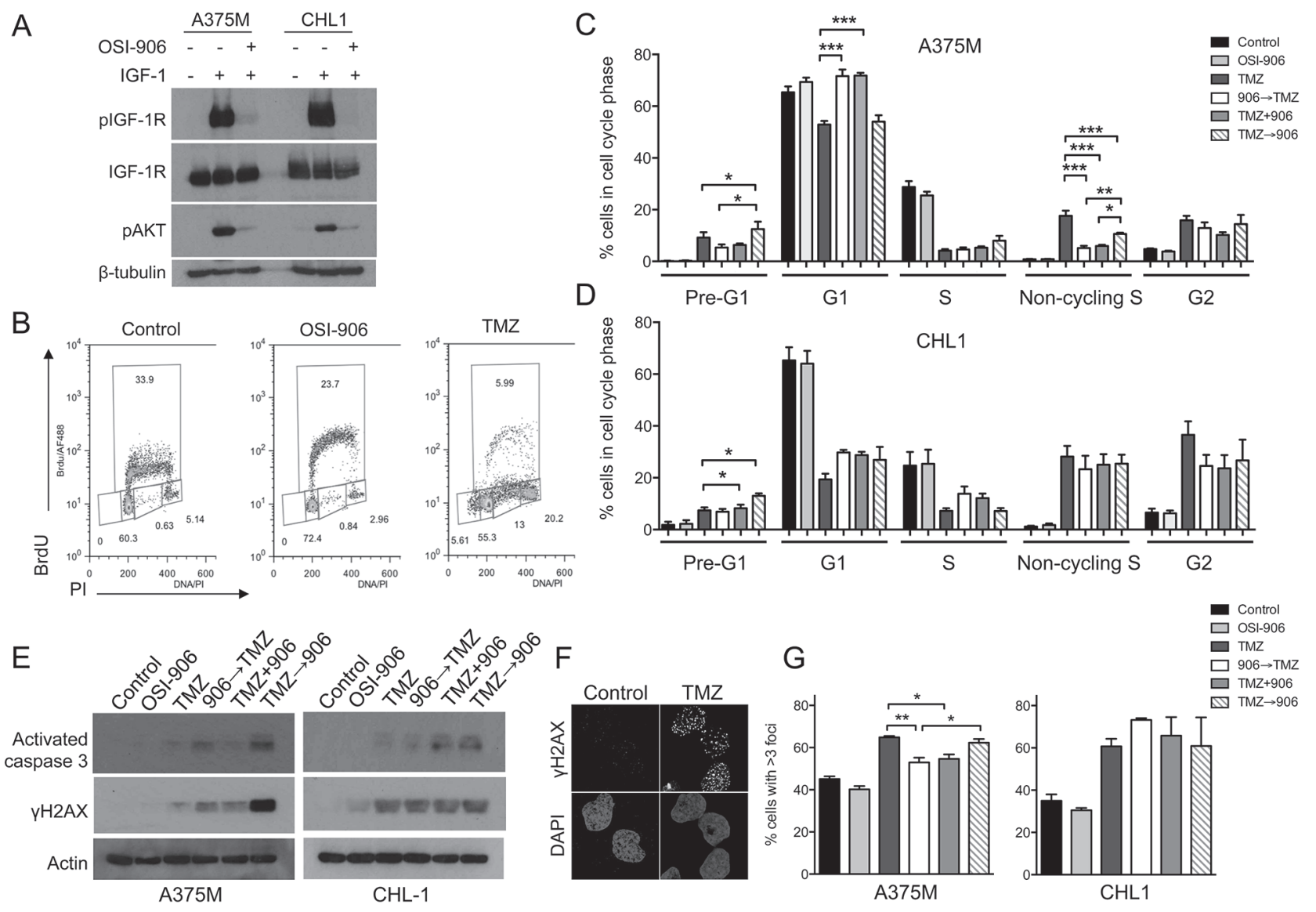

Figure 4: IGF-1R inhibition pre-TMZ induces G1 arrest and reduces DSB induction. A. Cells were treated with $300 \mathrm{nM}$ OSI-906 and IGF-1 as Figure 1D. B. A375M cells treated with solvent, $300 \mathrm{nM}$ OSI-906 or $300 \mu \mathrm{M}$ TMZ. After $72 \mathrm{hr}$, cell cycle profiles were determined by analysis of BrdU incorporation vs DNA content (PI staining). C. A375M, D. CHL1 cells treated with solvent, $300 \mathrm{nM}$ OSI-906, $300 \mu \mathrm{M}$ TMZ alone or with $300 \mathrm{nM}$ OSI-906 applied $24 \mathrm{hr}$ before, simultaneously or $24 \mathrm{hr}$ post-TMZ, and collected $72 \mathrm{hr}$ post-TMZ. Graphs: mean \pm SEM data from $n=4$ analyses in each cell line. Compared with TMZ alone, TMZ-treated/IGF-1R-inhibited cells showed significant differences in pre-G1, G1 and non-cycling S populations of A375M, and only in the pre-G1 population of CHL1 $\left({ }^{*} p<0.05,{ }^{*} p<0.01,{ }^{* * *} p<0.001\right)$. E. Cultures treated as C, D were lysed $72 \mathrm{hr}$ post-TMZ for western blotting. F. CHL1 cells were treated with solvent or $300 \mu \mathrm{M} \mathrm{TMZ}$ and after $72 \mathrm{hr}$ stained for $\gamma \mathrm{H} 2 \mathrm{AX}$. G. Cells were treated as C), D) and after 120 hr, 50-2300 cells per condition were analysed for $\gamma \mathrm{H} 2 \mathrm{AX}$ foci. Graphs: mean \pm SEM $\%$ cells with $>3$ foci. Pre- or co- inhibition of IGF-1R significantly reduced TMZ-induced foci in A375M $(* p<0.05, * * p<0.01$ compared with TMZ alone).

blotting data, we detected $\gamma \mathrm{H} 2 \mathrm{AX}$ foci in TMZ-treated cells (Figure 4F), and quantified changes in cells exposed to TMZ alone or with pre-, co- or post- treatment with OSI-906, as Figure 3C. As a single agent, TMZ induced more foci in CHL1 than A375M cells (Supplementary Figure S4C), consistent with relative TMZ sensitivities in viability assays (Table 1 ). There was no difference in TMZ-induced foci in IGF-1Ri-treated A375M or CHL1 cells at this $72 \mathrm{hr}$ time-point (Supplementary Figure S4C). In light of the cell cycle changes seen previously (Figure 4C), and the time needed to generate toxic DSBs, we repeated this assessment $120 \mathrm{hr}$ postTMZ. Here, we observed significant reduction in TMZinduced $\gamma \mathrm{H} 2 \mathrm{AX}$ foci in $\mathrm{A} 375 \mathrm{M}$ cells pre- or co-treated with OSI-906 compared with cells treated with TMZ alone or TMZ followed by OSI-906 (Figure 4G, left). These findings suggest reduced induction of DNA damage as a consequence of G1 accumulation of IGF-1R pre- or co- inhibited cells. In contrast, IGF-1R inhibition did not influence TMZ-induced $\gamma \mathrm{H} 2 \mathrm{AX}$ foci in CHL1 cells (Figure 4G, right), in which there were no sequencedependent changes in TMZ-sensitization (Supplementary Figure S3) or cell cycle distribution (Figure 4D).

\section{OSI-906 enhances sensitivity of melanoma xenografts to temozolomide}

To explore the therapeutic potential of these data, we tested whether OSI-906 is tolerable with TMZ in vivo, employing the sequential (TMZ $\rightarrow$ OSI-906) schedule identified as optimal in vitro (Figure 3D), and using A375M, known to be tumorigenic in vivo [27]. To mimic clinical treatment, TMZ was dosed on days 1-5 in Ora-Plus, as previously tested in glioblastoma [28]. 
After 5 days, TMZ-treated mice were divided into groups for IGF-1Ri dosing (Supplementary Figure S5A). OSI-906 is insoluble in aqueous solution, and has been previously dosed in tartaric acid [29]. In case this acid solvent could exacerbate toxicity, we compared OSI906 administration in tartaric acid, Ora-Plus or corn oil (Figure 5A). TMZ and OSI-906 were tolerable when administered sequentially with weight loss generally $<10 \%$, with the exception of OSI-906 in tartaric acid $(\sim 12.5 \%)$, although OSI-906-treated groups were not significantly different (Supplementary Figure S5A-S5B). TMZ induced a trend to tumor growth delay (Figure 5A, Supplementary Figure S5C), but this experiment was not powered to detect differences in tumor volume. Four hours after final OSI-906 dosing, blood and tumor were collected for immunohistochemical and pharmacokinetic analysis. Ki67 positivity was detectable in all tumors, with evidence of reduction in the TMZ-alone group (Figure 5B, 5C), paralleling the reduced S-phase fraction in cell cycle analysis (Figure 4C). Activated caspase 3 was clearly detectable in tumors treated with TMZ followed by OSI-906, but not in vehicle or TMZ alone groups (Figure 5B-5C). OSI-906 dosing achieved drug levels in tumor of $3700-5700 \mathrm{ng} / \mathrm{ml}(8.7-13.6 \mu \mathrm{M})$, and plasma of $\sim 4000-5600 \mathrm{ng} / \mathrm{ml}(9.3-13.3 \mu \mathrm{M}$; Figure 5D), corresponding to plasma levels achieved clinically
A
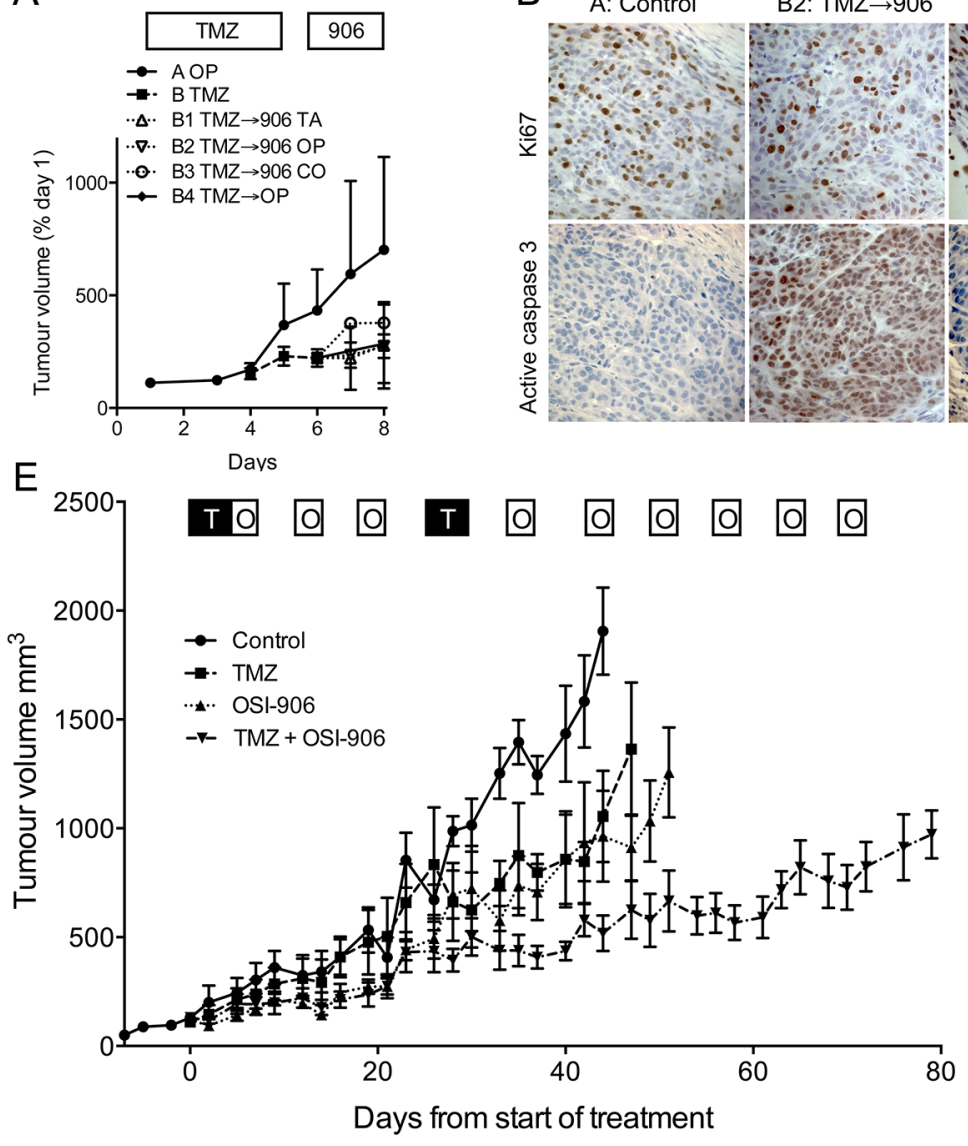
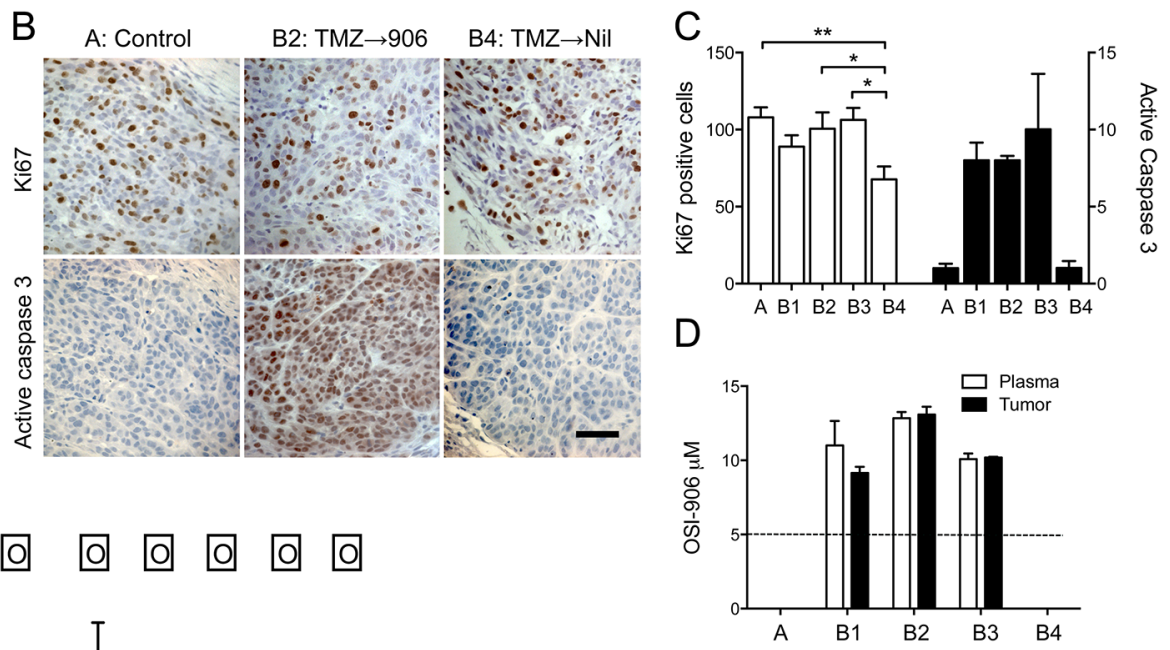

F

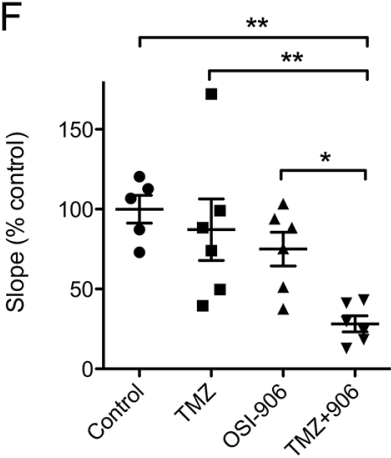

Figure 5: IGF-1R inhibition sensitizes melanoma to TMZ in vivo. A. Mice bearing A375M xenografts were treated with OraPlus (OP, Group A, 2 mice) or $50 \mathrm{mg} / \mathrm{kg}$ TMZ in Ora-Plus by gavage days 1-5 (Group B, 8 mice). On day 6, group B was randomly divided into 4 groups of 2 for gavage on days $6-8$ with $50 \mathrm{mg} / \mathrm{kg}$ OSI-906 in $25 \mathrm{mM}$ tartaric acid (TA, B1), Ora-Plus (OP, B2), corn oil (CO, B3), or vehicle (Ora-Plus) alone (B4). Graph: mean \pm range tumor volume (\% baseline). B. Tumors harvested 4 hr after final OSI-906 dosing were stained for Ki67 and activated caspase 3. Scale bar $50 \mu \mathrm{m}$. C. Quantification of Ki67 (white bars) and activated caspase 3 (black bars). Ki67 counts were lower in group B4 (TMZ alone; ${ }^{*} p<0.05,{ }^{* *} p<0.01$ ). Activated caspase 3 was detected only in tumors treated with TMZ followed by OSI-906. D. OSI-906 levels in plasma and tumors. Dotted line: steady state OSI-906 levels achieved at recommended Phase 2 dose [18]. OSI-906 levels in groups A (control) and B4 (TMZ alone) were below limits of quantitation: $\sim 20 \mathrm{ng} / \mathrm{ml}(0.05 \mu \mathrm{M})$ for plasma, $200 \mathrm{ng} / \mathrm{g}(0.5 \mu \mathrm{M})$ for tumor. E. Mice bearing A375M xenografts were treated with Ora-Plus (control), $50 \mathrm{mg} / \mathrm{kg} \mathrm{TMZ} \mathrm{(T),} 50 \mathrm{mg} / \mathrm{kg} \mathrm{OSI-}$ 906 (O) or combination treatment, scheduling OSI-906 to avoid administration immediately before/with TMZ. Graph: mean \pm SEM tumor volumes, $n=6$. F. Graph: linear regression analysis of slopes of tumor growth, showing individual data points and mean $\pm \mathrm{SEM}$ slope as $\%$ control. There were no differences in growth rates of control, TMZ or OSI-906 -treated tumors, and significant reduction in the combination group compared with each of the other groups $(* p<0.05, * * p<0.01)$. 
$[18,19]$. Ora-Plus was chosen to administer both TMZ and OSI-906, to assess effects on tumor growth.

Mice bearing A375M xenografts were treated with vehicle (Ora-Plus) alone, TMZ, OSI-906, or both drugs, using clinically relevant schedules, dosing TMZ on days $1-5$ and OSI-906 on three days per week $[1,18]$. This intermittent schedule allowed us to adopt the drugsequencing regimen (TMZ $\rightarrow$ OSI-906) that was more effective in vitro (Figure 3D). After a second cycle of TMZ, OSI-906 dosing continued on a D1-3 q7 day cycle (Figure 5E). Both TMZ and OSI-906 induced weight loss $<10 \%$, which in the case of OSI-906 was rapid onset, unaccompanied by distress, and recovering rapidly on days off-treatment (Supplementary Figure S5D). Effects on tumor growth are shown in Figure 5E. Untreated control tumors grew rapidly, achieving a volume of $1000 \mathrm{~mm}^{3}$ in $29 \pm 2$ days from the start of treatment. TMZ or OSI-906 caused minor growth delay, taking $36 \pm 6$ and $39 \pm 5$ days respectively to reach $1000 \mathrm{~mm}^{3}$, not significantly different from controls (Supplementary Figure S5E). Combination treatment induced significant growth delay, tumors taking $79 \pm 4$ days to attain $1000 \mathrm{~mm}^{3}$ ( $p<0.001$ compared with the other groups, Supplementary Figure S5E). Growth delay was also evident when evaluating the gradient of tumor growth (Figure 5F), which was reduced by TMZ or OSI-906 by $13 \%$ and $25 \%$ respectively compared with controls. If additive, combination treatment would induce $38 \%$ reduction; the observed reduction was $78 \%$, suggesting supra-additivity. Furthermore, survival was prolonged by the combination treatment compared with the other three groups (Supplementary Figure S5F). These results suggest that OSI-906 can be administered with TMZ to xenograft-bearing mice, and effects on melanoma growth are supra-additive compared with either agent alone.

\section{DISCUSSION}

Our results indicate that human melanoma cell lines show variable sensitivity to IGF-1Ri, consistent with data from large drug screens in which A375 and SKmel2 were more sensitive to OSI-906 and A2058, CHL1 and SKmel28 more resistant [30]. Here, some cell lines showed potent inhibition of proliferation and cell survival at clinically-achievable OSI-906 concentrations. Indeed, the Phase 1 study of continuous oral dosing of OSI-906 reported an objective partial response, converted by surgery into a highly durable complete response, in one of 3 melanoma patients [19]. In the current study, responses to OSI-906 were unrelated to levels of total or activated IGF-1R, consistent with clinical findings that IGF-1R expression does not predict sensitivity to IGF1R inhibition [31]. The most sensitive cell lines (501mel, A375, A375M; Table 1) harbor V600E BRAF; supporting activity in the context of activating RAS-RAF mutations, a study of synthetic lethal interactions identified
IGF-1R as a key driver of AKT phosphorylation in KRAS mutant NSCLC [32]. In addition, we noted that in the melanoma cell lines and an isogenic NSCLC model, loss of WT p53 correlated with resistance to IGF-1R inhibition. The association of WT p53 with sensitivity to IGF-1R inhibition was also reported using the non-ATPcompetitive IGF-1R inhibitor picropodophyllin [33], and may be relevant in selecting patients for treatment with IGF-1R inhibitory drugs.

The melanoma cell lines were relatively TMZ resistant, with $\mathrm{GI}_{50}$ and $\mathrm{SF}_{50}$ values above the clinical Cmax [1]. Our results indicate a correlation between intrinsic TMZ resistance and IGF-1R activation, and show that two different small molecule IGF-1R inhibitors sensitize human melanoma cells to TMZ. Both IGF$1 \mathrm{Ri}$ agents used here also inhibit INSR, and it would be informative to measure INSR expression in the melanoma cell line panel, to assess the contribution of this receptor to chemo-resistance. IGF-1R inhibitors have also been shown to enhance TMZ-sensitivity in neuroblastoma and medulloblastoma $[34,35]$. These and other studies implicated IGF-1R as a mediator of chemo-resistance via regulation of AKT activation, cell cycle progression and cell survival [34-36]. In our study, IGF-1R-inhibited melanoma cells showed enhanced TMZ-induced apoptosis, relatively minor at $24-48 \mathrm{hr}$, more substantial $72 \mathrm{hr}$ postTMZ in vitro, and much more striking in melanoma xenografts after 5 days of TMZ and 3 days of OSI-906 (Figure 5B, 5C). These differences could reflect the greater dependence on IGF-1R for anchorage-independent 3D vs 2D growth [37], and/or the more prolonged time-course of the in vivo experiment.

In addition to regulating apoptosis, two additional mechanisms may be relevant to IGF-1R-mediated chemo-resistance. Firstly, cytotoxic drugs are reported to induce IGF-1R activation, which can be suppressed by IGF-1R inhibition [38]. Secondly, there is evidence from our group and others that a functional IGF-1R is required for DSB repair by HR, which is required for the repair of replication-associated DSBs induced by TMZ [12, 13, $39,40]$. However, combining IGF-1Ri with phase-specific chemotherapy raises concerns that sensitization to TMZ could be antagonized by delayed cell cycle progression in IGF-1R-inhibited cells. While we found no evidence of antagonism, we did observe more effective chemosensitization in vitro using sequential (TMZ $\rightarrow$ OSI906) application (Figure 3D). We found no evidence that IGF-1R inhibition influenced removal of TMZ adducts (Supplementary Figure S2B-S2E), or delayed resolution of TMZ-induced DNA damage foci (Figure 4G), in contrast to the delayed repair of radiation-induced DSBs we reported recently [13]. There was, however, evidence that IGF-1R pre-inhibition caused accumulation of cells in G1, and reduced the subsequent yield of toxic TMZinduced $\gamma \mathrm{H} 2 \mathrm{AX}$ foci (Figure 4C, 4G). Co-application of IGF-1R inhibitor showed the same phenotype, which 
is logical given the delay in induction of TMZ-induced DSBs. We also noted that the differences in $\gamma \mathrm{H} 2 \mathrm{AX}$ signal on western blot of A375M cells (Figure 4E, left) appeared to be more marked than the changes in $\gamma \mathrm{H} 2 \mathrm{AX}$ foci (Figure 4G), possibly implicating other processes such as apoptosis or replication stress that induce $\gamma \mathrm{H} 2 \mathrm{AX}[25]$.

Previous studies have recognized that delayed cell cycle progression induced by targeted agents including IGF-1Ri show potential to protect tumors against phase specific cytotoxic drugs $[29,41]$. To our knowledge this protective effect has not until now been confirmed to be associated with reduced accumulation of toxic DNA damage. Unfortunately, this potential for antagonism has not been taken into account in the design of previous trials of IGF-1Ri with chemotherapy, and could have compromised outcomes in previous studies combining long half-life IGF-1R antibodies with phase-specific cytotoxic drugs [42-44]. Of potential relevance, we note that both $\mathrm{A} 375 \mathrm{M}$ and CHL1 cells harbor mutant $C D K N 2 A$, which encodes mutant $\mathrm{p} 16 \mathrm{INK} 4 \mathrm{a}$ with reduced capacity to inhibit the cyclin D1/CDK4 complex that regulates the G1 to $\mathrm{S}$ transition [45]. Despite this, A375M cells responded to IGF-1Ri with accumulation in G1. While CHL1 cells were chemo-sensitized by IGF-1Ri, this effect did not vary with sequence, and nor did they show sequence-related changes in cell cycle distribution. It is possible that lack of schedule-dependence in this cell line could be due to the presence of mutant p53, while A375M cells harbour WT p53, and/or a reflection of the lesser sensitivity of CHL1 cells to IGF-1R inhibition. Although CHL1 cells did not show sequence-dependent differences in chemosensitivity, post-TMZ inhibition of IGF-1R was as effective as pre- or co- treatment. Therefore, the cytotoxic $\rightarrow$ IGF-1Ri sequence is preferred for future studies. Our data confirm that this sequential combination treatment regimen is tolerable in vivo, inducing supra-additive inhibition of melanoma xenograft growth, using doses and schedules of both drugs consistent with clinical use $[1,18]$.

In summary, our data support the concept that the IGF axis is an important mediator of therapy resistance. By exploiting interactions between the cell cycle, DNA damage response and apoptosis induction, IGF1R inhibition can be an effective route to chemosensitization. Our findings also highlight the importance of scheduling when combining IGF-1R inhibitory drugs and other targeted agents with cytotoxic drugs that induce replication-associated DNA damage.

\section{MATERIALS AND METHODS}

\section{Cell lines and reagents}

Melanoma cell lines CHL1, SKmel2, HMCB were from American Type Culture Collection, A375, A357M, $501 \mathrm{mel}$ and COLO858 from Professor Colin Goding
(Ludwig Institute for Cancer Research Oxford), SKmel28 and A2058 from Cancer Research UK Cell Services, and SKmel23 from Professor Vincenzo Cerundolo (Weatherall Institute of Molecular Medicine Oxford). Subline B231 of H1299 p53 null non-small cell lung cancer (NSCLC) cells that express tetracycline-inducible wild-type p53 [20] was from Professor Xin Lu (Ludwig Institute for Cancer Research, Oxford). All cell lines were negative for mycoplasma (MycoAlert kit, Lonza Rockland Inc, Rockland US). AZ3801 and OSI-906 were provided by Elaine Kilgour (AstraZeneca) and Elizabeth Buck (OSI Pharmaceuticals/Astellas) respectively. TMZ was synthesized as described [46] and stored at $+4^{\circ} \mathrm{C}$ protected from light. For in vitro use, $10 \mathrm{mM}$ stock solutions of AZ3801, OSI-906, TMZ and O6BG (Sigma) in DMSO were aliquoted and stored at $-20^{\circ} \mathrm{C}$. Each agent was freshly diluted in culture medium to the correct final concentration. OSI-906 was freshly-prepared as a 10x stock in pre-warmed culture medium containing 10\% FCS and 5\% DMSO. Control cultures were treated with DMSO without drug.

\section{Western blotting, assays for viability, cell survival and apoptosis}

CellTiter Glo (Promega) viability assays and clonogenic assays were performed as in reference [13], using cultures growing in full medium supplemented with $10 \%$ FCS. Western blotting was performed as described [13], using antibodies to: IGF-1R (\#3027, Cell Signaling Technology, CST), phospho-Y1135/6 IGF-1R (\#3024, CST), phospho-S473 AKT (\#4051, CST), total AKT (\#9272, CST), phospho-T202/Y204 ERK 1/2 (\#4377, CST), total ERK 1/2 (\#4695, CST), MGMT (\#557045, BD Pharmingen), p53 (\#9282, CST) PARP (\#9542, CST) and actin (ab8224 or ab8227, Abcam). For each western blot shown, similar results were obtained in 1-2 further independent replicates. Viability and survival data were graphed and curve-fitted (GraphPad Prism v5) to interpolate $\mathrm{GI}_{50}$ and $\mathrm{SF}_{50}$ values (drug concentrations that suppress growth or survival to $50 \%$ of control values). Apoptosis was quantified by Apo-ONE ${ }^{\circledR}$ Homogenous Caspase 3/7 Assay (Promega).

\section{Assays for MGMT, AAG, O $^{6}$-meG and N7-meG}

MGMT and AAG activity assays were based on cleavage of ${ }^{32} \mathrm{P}$ labelled oligonucleotides containing single $O^{6}$-meG or ethenoadenine residues as described $[47,48]$. $\mathrm{O}^{6}$-meG levels in cellular DNA were determined by a modification of the MGMT activity assay [47] and levels of N7-meG adducts in cellular DNA were determined by an immunoslot blot method [49].

\section{Cell cycle analysis and immunofluorescence}

Cell cycle analysis and detection of $\gamma \mathrm{H} 2 \mathrm{AX}$ foci were performed according to $[13,50]$. Cells were 
pulsed with $10 \mu \mathrm{M}$ 5-bromo-2'-deoxyuridine (BrdU; Sigma-Aldrich) for $30 \mathrm{~min}$. Floating and adherent cells were collected, centrifuged at $250 \mathrm{~g}$ for $5 \mathrm{~min}$ and fixed in ice-cold $70 \%$ ethanol. After repeat centrifugation, cells were incubated in $2 \mathrm{M} \mathrm{HCl}$ containing $0.1 \mathrm{mg} / \mathrm{ml}$ pepsin at $23^{\circ} \mathrm{C}$ for $20 \mathrm{~min}$, washed with $\mathrm{PBS}$ and then with $2 \%$ FCS in PBS. Cells were resuspended in $2 \%$ FCS in PBS with $\alpha$ BrdU antibody (clone B44, BD Biosciences, 1:100) for $90 \mathrm{~min}$ at $23^{\circ} \mathrm{C}$. After adding $2 \% \mathrm{FCS}$ in PBS, the cells were pelleted again, resuspended in $2 \%$ FCS in PBS with Alexa Fluor 488 goat anti-mouse secondary antibody (Life Technologies, 1:200), and incubated for $60 \mathrm{~min}$ at $23^{\circ} \mathrm{C}$ in the dark. The cells were washed in PBS and resuspended in PBS containing $10 \mu \mathrm{g}$ propidium iodide and $10 \mu \mathrm{l}$ RNase $(20 \mathrm{mg} / \mathrm{ml}, 70 \mathrm{U} / \mathrm{ml}$; Invitrogen). After $15 \mathrm{~min}$ incubation at $23^{\circ} \mathrm{C}$, samples were analyzed on a Becton Dickinson FACScan using FlowJo v 8.8.7 software.

For immunofluorescent detection of $\gamma \mathrm{H} 2 \mathrm{AX}$ foci, cells were fixed with $4 \%$ paraformaldehyde with $0.1 \%$ Triton-X-100 in PBS for $10 \mathrm{~min}$, permeabilized in $0.3 \%$ Triton-X-100 in PBS for $10 \mathrm{~min}$ and blocked in 3\% BSA in PBS for $40 \mathrm{~min}$. Cells were incubated overnight at $4^{\circ} \mathrm{C}$ with antibody to S139 $\gamma \mathrm{H} 2 \mathrm{AX}$ (\#05-636, Upstate/ Millipore), diluted 1:1000 in 3\% BSA in PBS. After washing in PBS, bound antibody was detected with secondary antibody conjugated to Alexa Fluor 488 (InVitrogen; 1:1000 in 3\% BSA) and incubated for one hour at $23^{\circ} \mathrm{C}$ in the dark. Cells were DAPI-stained, images were acquired on an IN Cell Analyzer 1000 (GE Healthcare) and analysed using IN Cell Analysis 3.5 software (GE Healthcare).

\section{Xenograft studies}

In vivo work was carried out at Biomedical Services, John Radcliffe Hospital Oxford under a Home Office approved Project License. Xenografts were established by injecting $10^{7} \mathrm{~A} 375 \mathrm{M}$ cells with matrigel (BD Biosciences) into the flanks of 6-7 week old female Balb/c immunodeficient (nu/nu) mice. Tumors were measured 2-3 times a week, volumes were calculated as $\pi$ (length $\mathrm{x}$ width $\mathrm{x}$ height) $/ 6$, and mice were randomly allocated to treatment groups when tumor volumes reached 100 $200 \mathrm{~mm}^{3}$. Treatments were prepared fresh each day, administered by gavage as a suspension of $2.5 \mathrm{mg} / \mathrm{ml}$ TMZ or OSI-906. Mice were weighed daily when on treatment to adjust dosing to $50 \mathrm{mg} / \mathrm{kg}$, otherwise weekly. For initial tolerability and PK testing, mice were treated with $50 \mathrm{mg} / \mathrm{kg} \mathrm{TMZ}$ in Ora-Plus (Fagron UK) on days $1-5$, followed on days $6-8$ by $50 \mathrm{mg} / \mathrm{kg}$ OSI-906 in OraPlus, $25 \mathrm{mM}$ tartaric acid or corn oil. Controls were treated with Ora-Plus. Four hours after final OSI-906 dosing, the experiment was terminated, whole blood was obtained under anesthetic by cardiac puncture, and plasma was stored at $-80^{\circ} \mathrm{C}$. Tumors were halved for snap-freezing in liquid nitrogen, and formalin-fixation. OSI-906 levels in plasma and frozen tumor were analyzed by Andy Cooke and Mark Bittner (OSI Pharmaceuticals, Boulder CO). To test effects on tumorigenicity, mice were randomly allocated to four groups for dosing with Ora-Plus (control), TMZ on days 1-5 and 28-30, and/or OSI-906 on a three day per week schedule. Mice were sacrificed when tumors reached license limits or for loss of $\geq 20 \%$ baseline weight. Formalin-fixed, paraffin-embedded $4 \mu \mathrm{m}$ xenograft sections were stained using antibodies to Ki67 (clone SP6, \#VP-RM04, Vector Laboratories, 1:400 dilution) and active Caspase 3 (\#AF835, R\&D Systems, 1:1500). Ki67 positive nuclei were counted in 8 high-powered fields $\left(0.25 \mathrm{~mm}^{2}\right)$ for each section, and caspase 3 by the intensity (0-3 scale) and proportion (0-4) of positive staining, to generate Intensity x Percentage scores (IPS; 0-12).

\section{Statistical analysis}

Data were analyzed using GraphPad Prism v5, using $t$-tests to compare 2 groups, one-way ANOVA for multiple groups, Spearman correlation for association between variables, and linear regression to compare xenograft growth rates.

\section{ACKNOWLEDGMENTS AND FUNDING}

We are grateful to Elaine Kilgour, AstraZeneca UK for providing AZ3801 and Elizabeth Buck, Astellas Pharma US for providing OSI-906, Gautam Prasad and Daphne Haas-Kogan, Department of Radiation Oncology University of California CA, and Brett Carlson and Jann Sarkaria, Mayo Clinic Rochester MN for advice on TMZ dosing, Fred Dickinson, Kelly Frater and Anthony Cutts for technical assistance, Mark Bittner and Andy Cooke at OSI-Pharmaceuticals for OSI-906 PK analysis and Colin Goding, Wojciech Niedzwiedz and Alan MacIntyre for comments on the manuscript.

This work was supported by the NIHR Oxford Biomedical Research Centre, Molecular and Cellular Medicine Board of the MRC (G0601061), HEFCE Clinical Senior Lectureship to VMM, Royal College of Surgeons Fellowship to RR, Rosetrees Trust and Stoneygate Trust support to WPK, and Cancer Research UK support to GM.

\section{CONFLICTS OF INTEREST}

The authors have declared no conflict of interest.

\section{Editorial note}

This paper has been accepted based in part on peerreview conducted by another journal and the authors' response and revisions as well as expedited peer-review in Oncotarget. 


\section{REFERENCES}

1. Middleton MR, Grob JJ, Aaronson N, Fierlbeck G, Tilgen W, Seiter S, Gore M, Aamdal S, Cebon J, Coates A, Dreno B, Henz M, Schadendorf D, et al. Randomized phase III study of temozolomide versus dacarbazine in the treatment of patients with advanced metastatic malignant melanoma. J Clin Oncol. 2000; 18:158-66.

2. Quirt I, Verma S, Petrella T, Bak K, Charette M. Temozolomide for the treatment of metastatic melanoma: a systematic review. Oncologist. 2007; 12:1114-23.

3. Cancer Genome Atlas Network . Electronic address imo, Cancer Genome Atlas, N. Genomic Classification of Cutaneous Melanoma. Cell. 2015; 161:1681-96.

4. Solit DB, Rosen N. Resistance to BRAF inhibition in melanomas. N Engl J Med. 2011; 364:772-4.

5. Shin DS, Ribas A. The evolution of checkpoint blockade as a cancer therapy: what's here, what's next? Cur Opinion Immunol. 2015; 33:23-35.

6. Kanter-Lewensohn L, Dricu A, Girnita L, Wejde J, Larsson O. Expression of insulin-like growth factor-1 receptor (IGF-1R) and p27Kip1 in melanocytic tumors: a potential regulatory role of IGF-1 pathway in distribution of p27Kip1 between different cyclins. Growth Factors. 2000; 17:193-202.

7. Chitnis MM, Yuen JS, Protheroe AS, Pollak M, Macaulay VM. The type 1 insulin-like growth factor receptor pathway. Clin Cancer Res. 2008; 14:6364-70.

8. Sharma SV, Lee DY, Li B, Quinlan MP, Takahashi F, Maheswaran S, McDermott U, Azizian N, Zou L, Fischbach MA, Wong KK, Brandstetter K, Wittner B, et al. A chromatin-mediated reversible drug-tolerant state in cancer cell subpopulations. Cell. 2010; 141:69-80.

9. Villanueva J, Vultur A, Lee JT, Somasundaram R, Fukunaga-Kalabis M, Cipolla AK, Wubbenhorst B, Xu X, Gimotty PA, Kee D, Santiago-Walker AE, Letrero R, D'Andrea K, et al. Acquired resistance to BRAF inhibitors mediated by a RAF kinase switch in melanoma can be overcome by cotargeting MEK and IGF-1R/PI3K. Cancer Cell. 2010; 18:683-95.

10. Prithviraj P, Anaka M, McKeown SJ, Permezel M, Walkiewicz M, Cebon J, Behren A, Jayachandran A. Pregnancy Associated Plasma Protein-A links pregnancy and melanoma progression by promoting cellular migration and invasion. Oncotarget. 2015; 6:15953-65.

11. Yeh AH, Bohula EA, Macaulay VM. Human melanoma cells expressing V600E B-RAF are susceptible to IGF1R targeting by small interfering RNAs. Oncogene. 2006; 25:6574-81.

12. Turney BW, Kerr M, Chitnis MM, Lodhia K, Wang Y, Riedemann J, Rochester M, Protheroe AS, Brewster SF, Macaulay VM. Depletion of the type 1 IGF receptor delays repair of radiation-induced DNA double strand breaks. Radiother Oncol. 2012; 103:402-9.
13. Chitnis MM, Lodhia KA, Aleksic T, Gao S, Protheroe AS, Macaulay VM. IGF-1R inhibition enhances radiosensitivity and delays double-strand break repair by both nonhomologous end-joining and homologous recombination. Oncogene. 2014; 33:5262-73.

14. Kotsantis P, Jones RM, Higgs MR, Petermann E. Cancer therapy and replication stress: forks on the road to perdition. Adv Clin Chem. 2015; 69:91-138.

15. Yata K, Esashi F. Dual role of CDKs in DNA repair: to be, or not to be. DNA Repair (Amst). 2009; 8:6-18.

16. Margison GP. O6-methylguanine in DNA: Bad penny? Cell Cycle. 2010; 9:441-2.

17. Ji QS, Mulvihill MJ, Rosenfeld-Franklin M, Cooke A, Feng L, Mak G, O’Connor M, Yao Y, Pirritt C, Buck E, Eyzaguirre A, Arnold LD, Gibson NW, et al. A novel, potent, and selective insulin-like growth factor-I receptor kinase inhibitor blocks insulin-like growth factor-I receptor signaling in vitro and inhibits insulin-like growth factor-I receptor dependent tumor growth in vivo. Mol Cancer Ther. 2007; 6:2158-67.

18. Jones RL, Kim ES, Nava-Parada P, Alam S, Johnson FM, Stephens AW, Simantov R, Poondru S, Gedrich R, Lippman SM, Kaye SB, Carden CP. Phase I Study of Intermittent Oral Dosing of the Insulin-like Growth Factor-1 and Insulin Receptors Inhibitor OSI-906 in Patients With Advanced Solid Tumors. Clin Cancer Res. 2015; 21:693-700.

19. Puzanov I, Lindsay CR, Goff L, Sosman J, Gilbert J, Berlin J, Poondru S, Simantov R, Gedrich R, Stephens A, Chan E, Evans TR. A Phase I Study of Continuous Oral Dosing of OSI-906, a Dual Inhibitor of Insulin-Like Growth Factor-1 and Insulin Receptors, in Patients with Advanced Solid Tumors. Clin Cancer Res. 2015; 21:701-11.

20. Yap DB, Hsieh JK, Zhong S, Heath V, Gusterson B, Crook T, Lu X. Ser392 phosphorylation regulates the oncogenic function of mutant p53. Cancer Res. 2004; 64:4749-54.

21. Werner H, Karnieli E, Rauscher FJ, LeRoith D. Wild-type and mutant p53 differentially regulate transcription of the insulin-like growth factor I receptor gene. Proc Natl Acad Sci U S A. 1996; 93:8318-23.

22. Middleton MR, Lunn JM, Morris C, Rustin G, Wedge SR, Brampton MH, Lind MJ, Lee SM, Newell DR, Bleehen NM, Newlands ES, Calvert AH, Margison GP, et al. O6-methylguanine-DNA methyltransferase in pretreatment tumour biopsies as a predictor of response to temozolomide in melanoma. Br J Cancer. 1998; 78:1199-202.

23. Fu D, Calvo JA, Samson LD. Balancing repair and tolerance of DNA damage caused by alkylating agents. Nat Rev Cancer. 2012; 12:104-20.

24. Kaufmann WK. The human intra-S checkpoint response to UVC-induced DNA damage. Carcinogenesis. 2010; 31:751-65.

25. Lobrich M, Shibata A, Beucher A, Fisher A, Ensminger M, Goodarzi AA, Barton O, Jeggo PA. gammaH2AX foci 
analysis for monitoring DNA double-strand break repair: strengths, limitations and optimization. Cell Cycle. 2010; 9:662-9.

26. Solier S, Sordet O, Kohn KW, Pommier Y. Death receptor-induced activation of the Chk2- and histone H2AXassociated DNA damage response pathways. Mol Cell Biol. 2009; 29:68-82.

27. Middleton MR, Kelly J, Goodger S, Thatcher N, Margison GP. Four-hourly scheduling of temozolomide improves tumour growth delay but not therapeutic index in A375M melanoma xenografts. Cancer Chemother Pharmacol. 2000; 45:15-20.

28. Prasad G, Sottero T, Yang X, Mueller S, James CD, Weiss WA, Polley MY, Ozawa T, Berger MS, Aftab DT, Prados MD, Haas-Kogan DA. Inhibition of PI3K/mTOR pathways in glioblastoma and implications for combination therapy with temozolomide. Neuro-oncology. 2011; 13:384-92.

29. Zeng X, Zhang H, Oh A, Zhang Y, Yee D. Enhancement of doxorubicin cytotoxicity of human cancer cells by tyrosine kinase inhibition of insulin receptor and type I IGF receptor. Breast Cancer Res Treat. 2012; 133:117-26.

30. McDermott U, Sharma SV, Dowell L, Greninger P, Montagut C, Lamb J, Archibald H, Raudales R, Tam A, Lee D, Rothenberg SM, Supko JG, Sordella R, et al. Identification of genotype-correlated sensitivity to selective kinase inhibitors by using high-throughput tumor cell line profiling. Proc Natl Acad Sci U S A. 2007; 104:19936-41.

31. King H, Aleksic T, Haluska P, Macaulay VM. Can we unlock the potential of IGF-1R inhibition in cancer therapy? Cancer Treat Rev. 2014; 40:1096-105.

32. Molina-Arcas M, Hancock D, Steckel M, Downward J. Determination of synthetic lethal interactions in KRAS oncogene dependent cancer cells reveals novel therapeutic targeting strategies. Cancer Res. 2012; 72. Abstract nr 4164.

33. Wang Q, Wei F, Lv G, Li C, Liu T, Hadjipanayis CG, Zhang G, Hao C, Bellail AC. The association of TP53 mutations with the resistance of colorectal carcinoma to the insulin-like growth factor-1 receptor inhibitor picropodophyllin. BMC Cancer. 2013; 13:521.

34. Geoerger B, Brasme JF, Daudigeos-Dubus E, Opolon P, Venot C, Debussche L, Vrignaud P, Vassal G. Anti-insulinlike growth factor 1 receptor antibody EM164 (murine AVE1642) exhibits anti-tumour activity alone and in combination with temozolomide against neuroblastoma. Eur J Cancer. 2010; 46:3251-62.

35. Zhou H, Rao J, Lin J, Yin B, Sheng H, Lin F, Zhang N, Yang L. The insulin-like growth factor-I receptor kinase inhibitor NVP-ADW742 sensitizes medulloblastoma to the effects of chemotherapy. Oncol Rep. 2011; 25:1565-71.

36. Flanigan SA, Pitts TM, Eckhardt SG, Tentler JJ, Tan AC, Thorburn A, Leong S. The insulin-like growth factor I receptor/insulin receptor tyrosine kinase inhibitor PQIP exhibits enhanced antitumor effects in combination with chemotherapy against colorectal cancer models. Clin Cancer Res. 2010; 16:5436-46.

37. Valentinis B, Morrione A, Peruzzi F, Prisco M, Reiss K, Baserga R. Anti-apoptotic signaling of the IGF-I receptor in fibroblasts following loss of matrix adhesion. Oncogene. 1999; 18:1827-36.

38. Eckstein N, Servan K, Hildebrandt B, Politz A, von Jonquieres $G$, Wolf-Kummeth $S$, Napierski I, Hamacher A, Kassack MU, Budczies J, Beier M, Dietel M, Royer-Pokora B, et al. Hyperactivation of the insulin-like growth factor receptor I signaling pathway is an essential event for cisplatin resistance of ovarian cancer cells. Cancer Res. 2009; 69:2996-3003.

39. Trojanek J, Ho T, Del Valle L, Nowicki M, Wang JY, Lassak A, Peruzzi F, Khalili K, Skorski T, Reiss K. Role of the insulin-like growth factor $\mathrm{I} /$ insulin receptor substrate 1 axis in Rad51 trafficking and DNA repair by homologous recombination. Mol Cell Biol. 2003; 23:7510-24.

40. Roos WP, Nikolova T, Quiros S, Naumann SC, Kiedron O, Zdzienicka MZ, Kaina B. Brca2/Xrcc2 dependent HR, but not NHEJ, is required for protection against $\mathrm{O}(6)$ methylguanine triggered apoptosis, DSBs and chromosomal aberrations by a process leading to SCEs. DNA Repair (Amst). 2009; 8:72-86.

41. Schwartz GK, Shah MA. Targeting the cell cycle: a new approach to cancer therapy. J Clin Oncol. 2005; 23:9408-21.

42. Watkins D, Tabernero J, Schmoll H, Trarbach T, Ramos F, Howe J, Brown HM, Clark K, Hsu BD, Cunningham D. A randomized phase II/III study of the anti-IGF-1R antibody MK-0646 (dalotuzumab) in combination with cetuximab $(\mathrm{Cx})$ and irinotecan ( $\mathrm{lr}$ ) in the treatment of chemofractory metastatic colorectal cancer (mCRC) with wild-type (wt) KRAS status. J Clin Oncol. 2011; 29. abstr 3501.

43. Retraction. Phase II study of the anti-insulin-like growth factor type 1 receptor antibody CP-751,871 in combination with paclitaxel and carboplatin in previously untreated, locally advanced, or metastatic non-small-cell lung cancer. J Clin Oncol. 2012;30:4179.

44. Guha M. Anticancer IGF1R classes take more knocks. Nat Rev Drug Discov. 2013; 12:250.

45. Marzuka-Alcala A, Gabree MJ, Tsao H. Melanoma susceptibility genes and risk assessment. Methods Mol Biol. 2014; 1102:381-93.

46. Middleton MR, Kelly J, Thatcher N, Donnelly DJ, McElhinney RS, McMurry TB, McCormick JE, Margison GP. O(6)-(4-bromothenyl)guanine improves the therapeutic index of temozolomide against A375M melanoma xenografts. Int J Cancer. 2000; 85:248-52.

47. Watson AJ, Middleton MR, McGown G, Thorncroft M, Ranson M, Hersey P, McArthur G, Davis ID, Thomson D, Beith J, Haydon A, Kefford R, Lorigan P, et al. O(6)methylguanine-DNA methyltransferase depletion and 
DNA damage in patients with melanoma treated with temozolomide alone or with lomeguatrib. Br J Cancer. 2009; 100:1250-6.

48. Crosbie PA, Watson AJ, Agius R, Barber PV, Margison GP, Povey AC. Elevated N3-methylpurine-DNA glycosylase DNA repair activity is associated with lung cancer. Mutat Res. 2012; 732:43-6.

49. Harrison KL, Wood M, Lees NP, Hall CN, Margison GP, Povey AC. Development and application of a sensitive and rapid immunoassay for the quantitation of N7-methyldeoxyguanosine in DNA samples. Chem Res Toxicol. 2001; 14:295-301.

50. Pfister SX, Ahrabi S, Zalmas LP, Sarkar S, Aymard F, Bachrati CZ, Helleday T, Legube G, La Thangue NB,
Porter AC, Humphrey TC. SETD2-dependent histone H3K36 trimethylation is required for homologous recombination repair and genome stability. Cell Rep. 2014; 7:2006-18.

51. Tsao H, Goel V, Wu H, Yang G, Haluska FG. Genetic interaction between NRAS and BRAF mutations and PTEN/ MMAC1 inactivation in melanoma. J Invest Dermatol. 2004; 122:337-41.

52. Lu M, Breyssens H, Salter V, Zhong S, Hu Y, Baer C, Ratnayaka I, Sullivan A, Brown NR, Endicott J, Knapp S, Kessler BM, Middleton MR, et al. Restoring p53 Function in Human Melanoma Cells by Inhibiting MDM2 and Cyclin B1/CDK1-Phosphorylated Nuclear iASPP. Cancer Cell. 2013; 23:618-33. 